\title{
A study of the prosodic patterns of autism and normal children in the imitating declarative and interrogative sentences*
}

\author{
Jinhyung Lee ${ }^{1}$ Cheoljae Seong ${ }^{2, * *}$ \\ ${ }^{1}$ Speech-Language Pathology, Chungnam National University, Dejeon, Korea \\ ${ }^{2}$ Linguistics , Chungnam National University, Daejeon, Korea
}

\begin{abstract}
The prosody of children with autism spectrum disorders (ASD) has several abnormal features, including monotonous speech. The purpose of this study was to compare acoustic features between an ASD group and a typically developing (TD) group and within the ASD group. The study also examined audience perceptions of the lengthening effect of increasing the number of syllables. 50 participants were divided into two groups (20 with ASD and $30 \mathrm{TD})$, and they were asked to imitate a total of 28 sentences. In the auditory-perceptual evaluation, seven participants chose sentence types in 115 sentences. Pitch, intensity, speech rate, and pitch slope were used to analyze the significant differences. In conclusion, the ASD group showed higher pitch and intensity and a lower overall speaking rate than the TD group. Moreover, there were significant differences in s2 slope of interrogative sentences. Finally, based on the auditory-perceptual evaluation, only $4.3 \%$ of interrogative sentences produced by participants with ASD were perceived as declarative sentences. The cause of this abnormal prosody has not been clearly identified; however, pragmatic ability and other characteristics of autism are related to ASD prosody. This study identified prosodic ASD patterns and suggested the need to develop treatments to improve prosody.
\end{abstract}

Keywords: autism, prosody, acoustic analysis, declarative, interrogative

\section{1. 서론}

언어의 운율(prosody)은 억양(intonation), 리듬(rhythm) 그리 고 강세(stress)로 구성되어 있고 장단이 얹혀 소리의 높이, 세기, 길이(duration) 등의 적당한 변화를 통해 구어에서 실현된다 (Cutler \& Isard, 1980; Lee, 1992). 소리의 길이와 높이, 세기 등의
운율 요소는 상호 복합적인 작용을 통하여 각 언어의 고유한 리 듬을 형성한다. 한 나라의 언어를 습득할 때 가장 어렵게 여겨 지며 가장 마지막에 체득하게 되는 부분이기도 하다(Seong, 1995). 정상인들은 발달과정에서 운율을 자연스럽게 학습하게 되며 운율을 사용하여 전달하고자 하는 중요한 정보를 전달할 수 있다(Fox \& Hampton, 2008). 하지만 자폐 아동은 자연스러운

* 이 논문은 2019년 한국음성학회 봄 학술대회 발표논문을 수정, 보완한 것입니다.

** cjseong49@gmail.com, Corresponding author

Received 31 March 2020; Revised 17 April 2020; Accepted 18 April 2020

(c) Copyright 2020 Korean Society of Speech Sciences. This is an Open-Access article distributed under the terms of the Creative Commons Attribution NonCommercial License (http://creativecommons.org/licenses/by-nc/4.0) which permits unrestricted non-commercial use, distribution, and reproduction in any medium, provided the original work is properly cited. 
운율을 학습하기가 어려우며 그로 인해 정확한 의미와 정보 전 달이 어렵다.

자폐 아동의 음도는 높은 편이며 범위가 좁아 단조롭게 들린 다(Goldfarb et al., 1972). 자폐 아동의 단조로운 억양으로 인해 말하는 사람의 태도, 기분, 성격이나 비언어적인 표현이 어려워 단어가 갖는 단순한 의미 외의 의사 전달에 어려움이 있다(Lee, 1988). 일반 아동들은 문장의 문법적, 의미적 요소를 음도의 변 화로 표현하지만, 자폐 아동들은 음도 변화보다는 강도의 변화 로 표현한다고 보고한 연구도 있다(Baltaxe \& Simmons, 1985). 자 폐 아동들이 낱말의 순서에 따라 통사적, 의미론적 정보를 이용 하지 않고 읽기를 수행하였음을 짐작해볼 수 있다(Tager-Flusberg \& Thurber, 1993).

$\operatorname{Lim}(2009)$ 은 읽기과제에서 자폐 아동과 일반 아동 간 의문문 과 평서문의 운율 통제 능력 차이를 비교하였는데, 음도 차이 비교에서 고기능 자폐 아동이 정상 아동에 비해 높은 음도 평균 값을 보였다. 의문문에서는 두 집단 모두 문미 마지막 세 음절 에서 상승현상을 보였으며 평서문에서는 모두 하강현상을 보 였다. 강도 차이를 살펴본 결과, 고기능 자폐 아동이 정상 아동 에 비해 높은 강도를 사용하였다. 음절 길이의 경우, 의문문 과 제에서는 차이가 유의하지 않았지만 평서문 과제에서는 마지 막 두 음절에서 유의한 차이를 보였다.

$\operatorname{Kim}(2005)$ 은 고기능 자폐 아동의 억양 특성 연구에서 집단 내 평서문의 음도기울기 값을 비교하였다. 고기능 자폐 아동 집 단과 일반 아동 집단의 평서문 문장 길이에 따른 음도기울기 값 을 비교하였을 때, 긴 문장에서 음도기울기 값이 컸지만 통계적 으로 유의하지 않았다. 이는 우리말에서 F0기울기는 문장길이 에 따라 차이를 보이지 않는다는 $\mathrm{Ko}(1988)$ 의 연구 결과와 일치 하지만, Cooper \& Sorensen(1981)의 문장 읽기를 통한 실험 음성 학적 억양 연구에서 음도기울기는 문장길이에 영향을 받아 짧은 문장에서 음도기울기 값이 커진다는 결과와는 일치하지 않았다.

자폐 아동들의 억양모방능력에 대하여 연구한 Fletcher(1976) 는 일반 아동에 비해 자폐 아동들의 억양모방능력이 훨씬 떨어 진다고 보고하였으며 자폐 아동의 모방은 초분절적 요소까지 따라하는 것은 아니라고 하였다. 자폐 아동의 운율 치료 프로그 램으로 가장 많이 쓰이는 멜로디 치료프로그램에 따라말하기 를 통한 중재가 포함되어 있으며 대부분의 임상에서 따라말하 기를 통한 자폐 아동의 운율 중재가 이루어지고 있다. 자폐 아 동의 효과적인 운율치료를 위해 따라말하기 과제를 통한 자폐 아동의 음향학적 운율 분석 연구가 필요함을 알 수 있다.

현재 자폐범주성 장애 아동의 운율에 대한 연구는 대부분 고 기능 자폐범주성 장애 아동의 읽기 과제를 통한 평서문 운율 연 구로 이루어져 있다. 음도, 강도, 속도, 기울기의 음향학적 요소 를 모두 포함한 의문문 관련 연구는 없다. 여러 연구들 중 자폐 범주성 장애 아동의 따라말하기와 운율을 연관시킨 실험음성 학적 연구나 청지각적 연구도 없으며 평서문과 의문문 따라말 하기 과제에서 자폐범주성 장애 아동 집단 내에 평서문과 의문 문에 대한 음향학적 비교 연구가 부족하여 자폐범주성 장애 아 동의 평서문과 의문문 간 음성학적 운율 차이 규명에 어려움이
있다. 또한, 짧은 문장일수록 음도 기울기 값이 커진다는 연구 (Cooper \& Sorensen, 1981) 결과가 있지만 문미 음절수를 체계적 으로 증가시키며 측정한 음도 기울기 차이 분석 연구는 없다. 문미 음절수를 1 음절부터 5 음절까지 체계적으로 증가시키면서 분석하였을 때 음절수 증가 효과가 있는지 실험을 통한 검증이 필요하다. 이는 임상적으로 장애 아동의 의문문 치료에서 문장 선별과 의문문표현 증진 난이도 조절을 위한 효과적 중재 접근 에 필요한 기초자료로 역할을 할 수 있다. 이러한 필요성과 선 행연구들에 근거하여 본 연구는 문장 따라말하기 과제에서 자 폐범주성 장애 아동 집단과 일반 아동 집단 간의 평서문과 의문 문 모방을 통한 운율의 특징적 차이를 규명하였다. 동시에 어말 음절의 길이에 따라 의문문의 음도 기울기에 변화가 생기는지 알아보고 자폐범주성 장애 아동의 의문문 산출과 청자의 지각 과의 관계를 살펴보았다.

\section{2. 연구방법}

\section{1. 연구대상}

본 연구의 대상은 세종시와 대전 지역에 거주하며 생활연령 이 만 7-12세 사이인 자폐범주성 장애 아동 20명(남자 13명, 여 자 7명), 생활 연령을 일치시킨 초등학생 일반 아동 30 명(남자 19 명, 여자 11명)을 비교대조집단으로 선정하여 총 50명을 대상 으로 진행하였다. 두 집단의 대상자가 충분하지 않으며 정규분 포를 만족하지 못하는 요소가 존재함으로 비모수 검정방법인 Mann-Whitney U Test를 실시하였다. 대상자들의 기본 정보는 표 1에 제시하였다. 두 집단은 생활연령에서 통계상 유의한 차 이를 보이지 않았다 $(Z=-.476, p=.634)$. 정상발달 아동의 경우 7 세 이후에 조음기관 운동 통제 능력과(Sharkey \& Folkins, 1985) 문장 따라말하기 수행력이 안정되어(Park, 2003) 집단 연령을 7 세 이후로 통제하였다.

일반 아동의 선정기준은 아래와 같다. 1) 부모나 교사에 의해 언어능력이나 지적능력이 정상으로 보고되고 기타 발달에 문 제가 없는 것으로 보고된 아동, 2) 시각이나 청각 등에 문제를 보이지 않는 아동, 3 ) 변성기가 오지 않은 아동, 4) 수용·표현 어 휘력 검사(REVT) 결과, 정상 언어발달 범주에 속하는 아동, 5) 우리말 조음음운평가(U-TAP) 단어 검사 결과, 자음정확도 $95 \%$ 이상에 속하는 아동. 자폐범주성 장애 아동의 선정기준은 다음 과 같다. 1) 언어연령이 생활연령보다 낮은 것을 고려하여 수용 어휘능력이 만 4세 이상으로 평가된 아동, 2) 소아정신과 또는 신경 정신과에서 DSM-5의 진단기준에 입각하여 자폐범주성장 애(autism spectrum disorders, ASD)로 진단받은 아동, 3) 시각이 나 청각 등에 문제를 보이지 않는 아동, 4) 변성기가 오지 않은 아동, 5) 자음정확도 $90 \%$ 이상으로 조음 오류가 문장이나 억양 산출에 영향을 미치지 않게 경미한 경우에 속하는 아동. 
표 1. 연구 대상자 정보

Table 1. The information of subjects (informants)

\begin{tabular}{c|c|c|c|c|c|c}
\hline & \multicolumn{2}{|c|}{$\mathrm{TD}$} & \multicolumn{2}{c|}{$\mathrm{ASD}$} & \multicolumn{2}{c}{} \\
\hline & 평균 & 표준편차 & 평균 & 표준편차 & $Z$ & $p$ \\
\hline $\begin{array}{c}\text { 생활연령 } \\
\text { (개월) }\end{array}$ & 110.53 & 20.416 & 112.45 & 18.092 & -.476 & .634 \\
\hline
\end{tabular}

TD, typically developing; ASD, autism spectrum disorders.

2.2. 연구 절차

\subsection{1. 음성 산출 과제}

본 실험에 앞서 소음환경과 격리된 독립된 공간에서 개별적 으로 아동과 검사자만 참석한 상황에서 아동의 기본정보(이름 과 생년월일)를 물어본 후 REVT와 U-TAP 평가 과정을 설명한 후 언어 평가가 진행되었다. 언어평가 후, 주변 소음이 차단된 독립된 공간에서 녹음을 진행하였다. TASCAM DR-05(TEAC, USA) 녹음기를 아동의 입에서 약 $15-20 \mathrm{~cm}$ 정도 떨어진 위치에 트라이포드로 고정한 후 모노로 녹음하였다 $(44,100 \mathrm{~Hz}$ 추출률 (sampling rate), 16 bits 양자화(quantization) 조건). 본 연구에 앞 서 연구자는 아동에게 평서문과 의문문 따라말하기 과제에 대 해 아동이 평서문과 의문문을 따라말하게 될 것을 설명하였다. 의문문에 대해서는 '이건 물어보는 말이야'라고 추가로 설명을 하였다. 예비 녹음 세션 과정으로 연구자는 평서문 나무가 많 아.'와 의문문 '나무가 많아(`)?’를 들려주고 문장별로 1 회씩 총 2회로 연구자의 발화를 따라 말하도록 하였다. 모든 문장은 문미가 1-5음절로 구성된 2어절 문장으로 평서문 14 문장, 의문 문 14 문장, 총 28 문장이 본 실험에 사용되었다. 연습 세션 이후, 총 28 문장 따라말하기 과제를 실시하였다. 어휘는 취학 전 아동 들이 이해할 수 있고 표현할 수 있는 어휘들로 MCDI-K 유아용 에서 선정하였다. 따라말하기 과제에서의 문장들은 다음과 같 은 점을 고려하여 구성하였다. 1) 일반 아동 5세가 따라말할 수 있는 정도의 구문구조를 포함해야 한다. 2) 언어장애 아동에게 나타나는 오류 구조를 포함해야 한다. 3) 검사 문장은 너무 길지 않게 해야한다(Sceartz \& Daly, 1976). 표 2와 표 3에 실험 자료 문장목록을 정리하였다. 표 2에 제시된 2-3음절로 이루어진 문 장은 일반 아동 집단과 자폐범주성 장애 아동 집단 간 문법 유 형에 따른 음향학적 특성 분석에 사용되었고, 표 3 에 제시된 1-5 음절로 구성된 문장은 문미 음절 수 증가 효과에 따른 어말 음 도기울기 분석에 사용되었다.
표 2. 문미가 2-3음절로 구성된 문장 목록

Table 2. The list of sentences finalized with 2-3 syllable words

\begin{tabular}{c|c|c}
\hline 문미 길이 & 평서문 & 의문문 \\
\hline \multirow{5}{*}{ 2음절 } & 문 열어. & 문 열어? \\
& 나무가 많아. & 나무가 많아? \\
& 내일 만나. & 내일 만나? \\
& 이제 내려. & 이제 내려? \\
& 머리 말려. & 머리 말려? \\
& 여기 놔요, & 여기 놔요? \\
\hline \multirow{5}{*}{ 3음절 } & 나비가 날아요. & 나비가 날아요? \\
& 엄마가 노래해. & 엄마가 노래해? \\
& 머리 말려요. & 머리 말려요? \\
& 여기 놨어요. & 여기 놨어요? \\
\hline
\end{tabular}

표 3. 문미가 1-5음절로 구성된 문장 목록

Table 3. The list of sentences consisted of 1-5 syllable final word

\begin{tabular}{c|c|c}
\hline 문미 길이 & 평서문 & 의문문 \\
\hline 1음절 & 여기 놔. & 여기 놔? \\
\hline \multirow{2}{*}{ 2음절 } & 여기 놔요 & 여기 놔요? \\
& 머리 말려. & 머리 말려? \\
\hline \multirow{2}{*}{ 3음절 } & 머리 말려요. & 머리 말려요? \\
& 여기 놨어요. & 여기 놨어요? \\
\hline \multirow{2}{*}{ 4음절 } & 머리 말렸어요. & 머리 말렸어요? \\
& 머리 말릴 거에요. & 머리 말릴 거에요? \\
\hline 5음절 & 여기 놓을 거에요. & 여기 놓을 거에요? \\
\hline \multicolumn{2}{|c}{}
\end{tabular}

\subsection{2. 청지각 과제}

일반 아동 30 명과 자폐범주성 장애 아동 20 명의 평서문과 의 문문 녹음 파일을 대상으로, 한 아동 당 2-3음절로 구성된 특정 의 평서문, 의문문 1 문장을 선정하였다( 1,000 문장 중 100 문장). 1,000 개의 문장 모두를 청지각 과제로 선택하기에 평가자의 집 중이 어려워 평가의 결과에 영향을 미칠 수 있어 10-20분 이내 로 평가를 할 수 있게 무선(random)으로 100 개의 문장을 선정하 였다. 평가자내 일치도 평가를 위하여, 이미 선정된 실험 자극 셋에서 무선(random)으로 선택한 문장에 대해 이와 동일한 15 개의 dummy 문장을 추가하여 총 1,000 개의 문장 중 115 문장 (8.7\%)으로 실험 자극을 구성하였다. 이 문장들을 Praat에서 제 공하는 ExperimentMFC를 이용하여 청취 반복횟수 3 회까지 허 용하는 실험용 플랫폼을 스크립팅하였다. 청지각 평가자는 청 력에 문제가 없고 대학교 이상의 학력을 가진 한국어를 모국어 로 사용하는 만 20 세에서 50 세 사이의 한국인 일반 성인으로 모 집하였다. 남자 3 명, 여자 4명으로 총 7명이 평가에 참여하였다. 평가자는 한국어 평서문과 의문문을 일반인 기준에서 선택하 게 했고, ‘모르겠다' 버튼을 두었을 경우 청자의 판단을 ‘모르겠 다'로 미루어버릴 확률이 높을 수 있으므로 하나를 강제로 선택 하는 방법으로 $(2 \mathrm{AFC})$ 엄격하게 실험 설계를 했다. 실험 전 연구 자는 조용한 환경에서 평가자들에게 실험 방법에 대해 설명한 후 예비 실험을 실시하였다. 본 실험에서 평가자들은 무선 (random)으로 제시되는 115 개의 자극을 듣고 화면에 보이는 두 개의 선택지(평서문, 의문문) 중 하나를 강제 선택하였다(2AFC). 문장을 듣고 평서문으로 느낄 경우 ‘평서문’을 선택하고, 의문 문으로 들렸을 경우 ‘의문문’을 선택하게 하였다. 
2.2.3. 음성 자료 분석

녹음한 음성 자료는 $\mathrm{kPhonetica} 2.08^{1}$ 로 자동으로 초벌 분절, 레이블링하였다(그림 1).

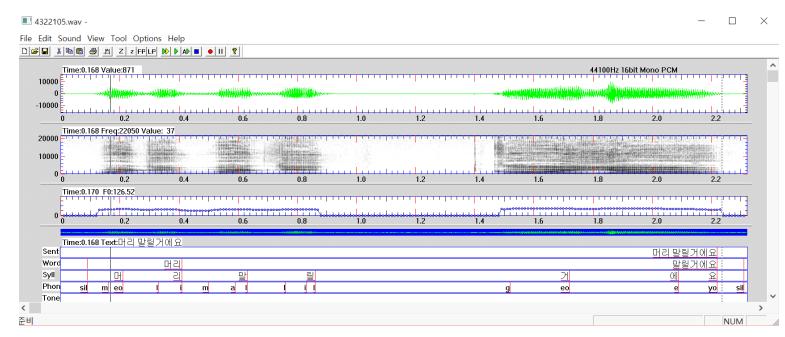

그림 1. k-phonetica로 자동 분절한 화면

Figure 1. Screen copy of automatic segmentation \& labeling by kPhonetica

이후 자동 분절된 자료의 오류를 확인하고 정밀한 분석을 위 해 문장, 단어, 음절, 음도기울기의 4개 층위(tier)로 구성된 Praat (version 6.0.49) 편집창 위에서 음도, 강도 곡선을 고려하여 정밀 하게 분절 조절하였다. 레이블링 후 Praat 스크립트를 이용하여 음향 분석하였다. 12 개의 변수는 음도, 강도, 속도, 기울기에 따 라 구분하였다.

분석은 자동화된 스크립트를 이용하여 프랏 객체창의 object에 서 직접 query command를 불러내어 진행하였다. 피치는 pitch(ac) 즉 자동상관 방식으로 구하였는데 마루와 천정값은 각각 120 과 $500 \mathrm{~Hz}$ 로 설정하였다. intensity object는 객체산출시 요구하는 최소피치를 $100 \mathrm{~Hz}$, time step은 $8 \mathrm{~ms}$, 그리고 녹음시 디폴트로 개입되는 constant pressure level을 없애기 위하여 'subtract mean value'를 'on' 시켰다. 분석에 사용된 음향 변수는 표 4에 제시하 였고 표 5에서 각 변수에 대해 설명하였다.

표 4. 분석에 이용된 12 개의 음향변수

Table 4. 12 Acoustic variables used in analysis

\begin{tabular}{c|l}
\hline & \multicolumn{1}{|c}{ 음향 변수 } \\
\hline 음도 & PitchMedian, PitchRange, PitchDev, qtone_90 \\
\hline 강도 & IntMedian, IntRange, IntDev \\
\hline 속도 & SpeakingRate, a_rate \\
\hline 기울기 & s2_Slope, s2_meanAbsSlope, diff_s2_Slope \\
\hline
\end{tabular}

1 http://blog.naver.com/cj_seong에서 다운로드.
표 5. 분석에 이용된 음향변수의 설명

Table 5. Description of the acoustic variables used in analysis

\begin{tabular}{|c|c|}
\hline 음향 변수 & 설명 \\
\hline Pitch & $\begin{array}{l}\text { 음도 중앙값으로 말소리 높낮이의 범위, 평균, } \\
\text { 표준편차 측정 시 주변에 퍼져있는 분포에서 } \\
\text { 중앙에 위치하는 값 }(\mathrm{Hz})\end{array}$ \\
\hline Pitch & $\begin{array}{l}\text { 음도 범위로 말소리 높낮이의 최대값에서 쇠 } \\
\text { 소값을 뺀 값 }(\mathrm{Hz})\end{array}$ \\
\hline Pitcl & $\begin{array}{l}\text { 말소리 음도 표준편차 }(\mathrm{Hz}) \text {. 값이 클수록 편차 } \\
\text { 가 크다. }\end{array}$ \\
\hline qton & $\begin{array}{l}\text { 쿼터톤 } 90 \text { 은 } 100 \text { 개로 쪼갠 높낮이 중 } 90 \text { 번째 } \\
\text { F0 값을 분자로 갖는 값 }(\mathrm{Hz})\end{array}$ \\
\hline IntM & $\begin{array}{l}\text { 강도 중앙값으로 세기의 범위, 평균, 표준편차 } \\
\text { 측정 시 주변에 퍼져있는 분포에서 중앙에 위 } \\
\text { 치하는 값 }(\mathrm{dB})\end{array}$ \\
\hline IntR & $\begin{array}{l}\text { 강도 범위로 강도의 최대값에서 최소값을 뺀 } \\
\text { 값(dB) }\end{array}$ \\
\hline IntDev & 강도의 표준편차 $(\mathrm{dB})$. 값이 클수록 편차가 크다. \\
\hline Speaki & $\begin{array}{l}\text { 전체 문장 발화시간을 분모로, 문장 음절수를 } \\
\text { 분자로 하여 측정한 말 속도 값(nsyl/sec) }\end{array}$ \\
\hline$a_{-}$ & $\begin{array}{l}\text { 발화시간에서 쉼 시간을 제외한 조음시간을 } \\
\text { 분모로, 문장 음절수를 분자로 하여 측정한 조 } \\
\text { 음 속도 값 }(\mathrm{nsyl} / \mathrm{sec})\end{array}$ \\
\hline s2_Slope & 문미 억양구 회귀(최소제곱법) 음도기울기 \\
\hline $\begin{array}{l}\text { s2_mean } \\
\text { AbsSlope }\end{array}$ & $\begin{array}{l}\text { 문미 억양구 억양 굴곡 변이량. Frame 단위 편 } \\
\text { 차 절대값의 총합을 지속시간으로 나눈 값 } \\
(\mathrm{Hz} / \mathrm{sec})\end{array}$ \\
\hline diff_s2_Slope & $\begin{array}{l}\text { 문미 말 } 2 \text { 개 음절 변화량 기울기. 음도 변화량 } \\
\text { 값을 시간 변화량으로 나눈 값 }\end{array}$ \\
\hline
\end{tabular}

조음속도를 계산하기 위한 묵음 구간은 다음과 같은 기준으 로 결정하였다. 프랏 에디터 창의 dynamic range $70 \mathrm{~dB}$, intensity 50-100 dB 세팅 조건, pitch 120-600 Hz 설정 조건에서 묵음구간 (silent interval)으로 관찰되는 $50 \mathrm{msec}$ 이상의 구간을 쉼으로 간 주하였으며 모음으로 앞 어절이 종결되는 경우 쉼구간의 출발 포인트는 모음의 두번째, 세 번째 포먼트가 공통으로 종결되는 지점으로 하였다. qtone_90은 각 데이터의 전체 피치 레인지를 청지각적 관점에서 고려할 때 $90 \%$ ile에 해당하는 지점이다. 청 지각적 관점에서 데이터 영역 최대값을 이용해서 정규화된 값 으로 변환할 수도 있지만 최대값은 우연한 outlier가 등장할 확 률이 높으므로 상대적으로 안정된 권역인 $90 \%$ ile 값을 이용하 여 로그스케일로 정규화하여 최종 데이터로 삼았다.

\section{3. 통계}

통계 처리는 SPSS 23(IBM, USA)을 이용하였다. 청지각 실험 에서는 평가자 내 일치도 검정을 위해 교차분석의 감마(Gamma) 와 카파(Kappa) 측도를 이용하였으며, 평가자 간 신뢰도 검정을 위해 ICC(Intraclass Correlation Coefficient)를 측정하였다. 평서 문과 의문문에서 일반 아동과 자폐범주성 장애아동 두 집단 별 로 평가자의 의문문 정반응 분포를 살펴보기 위해 카이제곱 검 정을 실시하였다. 음향특성에 대한 통계는 12 개의 음향 변수를 
종속변수로, 집단(일반, 자폐범주성 장애)과 문법 유형(평서문, 의문문)을 고정 변수(fixed factors)로, 2-3음절 10 개의 문장을 무선 변수(random factor)로 포함한 3원 혼합모형 분산분석(3-way mixed effects ANOVA)을 실시하였다. 사후 검정은 다중비교(multiple comparison)로 나타나는 1종 오류 통제를 위해 Bonferroni 검정을 적용하였다. 길이증가 효과를 보기위한 통계로는 3 개의 음도기 울기 변수를 종속변수로, 집단(일반, 자폐범주성 장애)과 문법 유형(평서문, 의문문)을 고정변수로, $1-5$ 음절로 이루어진 8 문장 을 무선 변수(random factor)로 포함한 3원 혼합 모형 분산분석 (3-way mixed effects ANOVA)를 실시하였다. 사후 검정은 다중 비교(multiple comparison)로 나타나는 1종 오류 통제를 위해 Bonferroni 검정을 적용하였다.

2.4. 신뢰도

2.4.1. 평가자 내 일치도(Intra-rater agreement correlation coefficient) 개별 평가자 내 일치도가 매우 높아 제외할 평가자가 없어 남 녀 평가자 7명 모두를 대상으로 평가자 내 신뢰도를 검정하였 다. 결과는 표 6에 제시하였다. 감마계수 값이 .997 , 카파계수 값 이 .906으로 매우 높은 일치도를 보이며 유의하였다( $p<.0001)$.

표 6. 평가자 내 일치도 결과

Table 6. The result of Intra-rater agreement test (kappa \& gamma)

\begin{tabular}{c|c|c}
\hline & 상관계수 $(r)$ & 유의확률 $(p)$ \\
\hline 감마 & $.997^{* * *}$ & .000 \\
\hline 카파 & $.906^{* * *}$ & .000 \\
\hline${ }^{* * *} p<.0001$. & \multicolumn{2}{|l}{}
\end{tabular}

2.4.2. 평가자 간 신뢰도

평가자 간 신뢰도를 검정하기 위해 7명의 반응 데이터 값으 로 급간내 상관계수(ICC)를 구하였다. 결과는 표 7에 제시하였 다. ICC로 평가자 간 신뢰도를 검정한 결과 Cronbach's Alpha 값 의 평균측도가 .988로 매우 높은 신뢰도를 보이며 유의하였다 $[\operatorname{AM}(99,594)=.988, p<.0001]$.

표 7. 평가자 간 신뢰도 결과

Table 7. The result of Inter-rater reliability (ICC)

\begin{tabular}{l|c|c|c|c}
\hline & 급내 상관관계 & 자유도 1 & 자유도 2 & 유의확률 $(p)$ \\
\hline 단일 측도 & $.923^{* * *}$ & 99 & 594 & .000 \\
\hline 평균 측도 & $.988^{* * *}$ & 99 & 594 & .000 \\
${ }^{* * * *} p<.001$. &
\end{tabular}

\section{3. 연구 결과}

3.1. 일반 아동 집단과 자폐범주성 장애 아동 집단 간 문법 유형에 따른 음향학적 특성

\subsection{1. 음도(pitch) 차이 분석}

모든 음도 변수는 문장 무선효과가 유의하지 않았다. 집단과
문법 유형에 따른 분산분석의 결과는 표 8 에 제시하였다. 음도 변수 분석 결과, 4개의 음도 변수 중 PitchRange(음도 범위), PitchDev(음도 표준편차)와 qtone_90(쿼터톤_90; semi-tone의 1/2 scale 수준에서 $110 \mathrm{~Hz}$ 를 기준치로 측정한 문장전체 음도의 $90 \%$ ile relative pitch)이 집단과 문법에 따른 상호작용 효과에서 통계적으로 유의한 차이를 보였다. 이에 대해 Bonferroni 사후검 정을 실시하여 세부적인 양상을 살펴보았다. 표 9은 문법 유형 별 두 집단의 음도 변수 사후검정 결과다. 각 음도 변수에서 문 법 유형별로 집단 간 차이를 살펴보았을 때, 평서문에서는 자폐 범주성 장애 아동 집단이 모든 변수에서 음도 값이 높았지만 의 문문에서는 음도 중앙값만 유의하게 높았고 음도 표준편차는 낮고 음도 범위가 일반 아동 집단에 비해 좁았다.

표 8. 음도 변수의 three-way mixed effects ANOVA 검정 결과 Table 8. The result of three-way mixed effects ANOVA on the pitch variables

\begin{tabular}{|c|c|c|c|c|}
\hline 변수 & 주효과 또는 상호작용 & 자유도 & $F$ & $p$-value \\
\hline \multirow{3}{*}{ PitchMedian } & 집단 & 1 & $93.696^{* * *}$ & .000 \\
\hline & 문법 & 1 & .510 & .475 \\
\hline & 집단×문법 & 1 & .630 & .428 \\
\hline \multirow{3}{*}{ PitchRange } & 집단 & 1 & 2.298 & .130 \\
\hline & 문법 & 1 & $81.713^{* * *}$ & .000 \\
\hline & 집단×문법 & 1 & $68.820^{* * *}$ & .000 \\
\hline \multirow{3}{*}{ PitchDev } & 집단 & 1 & 1.404 & .236 \\
\hline & 문법 & 1 & $70.585^{* * *}$ & .000 \\
\hline & 집단×문법 & 1 & $51.889^{* * *}$ & .000 \\
\hline \multirow{4}{*}{ qtone_90 } & 집단 & 1 & $18.018^{* * *}$ & .000 \\
\hline & 문법 & 1 & $19.199^{* * *}$ & .000 \\
\hline & 집단×문법 & 1 & $10.591^{* *}$ & .001 \\
\hline & 오차 & 981 & & \\
\hline
\end{tabular}

표 9. 문법 유형 별 집단에 대한 음도 변수의 Bonferroni 사후검정 결과 Table 9. Bonferroni post-hoc test on the pitch variables on groups by sentence types

\begin{tabular}{c|c|c|c|c|c}
\hline 변수 & 문법 & 집단(I) & 집단 $(\mathrm{J})$ & 평균차이(I-J) & $p$-value \\
\hline \multirow{2}{*}{ PitchMedian } & 평서 & 일반 & 자폐 & $-24.507^{* * *}$ & .000 \\
\cline { 2 - 6 } & 의문 & 일반 & 자폐 & $-28.885^{* * *}$ & .000 \\
\hline \multirow{2}{*}{ PitchRange } & 평서 & 일반 & 자폐 & $-44.170^{* * *}$ & .000 \\
\cline { 2 - 6 } & 의문 & 일반 & 자폐 & $30.520^{* * *}$ & .000 \\
\hline \multirow{2}{*}{ PitchDev } & 평서 & 일반 & 자폐 & $-9.838^{* * *}$ & .000 \\
\cline { 2 - 6 } & 의문 & 일반 & 자폐 & $7.059^{* * *}$ & .000 \\
\hline \multirow{2}{*}{ qtone_90 } & 평서 & 일반 & 자폐 & $-3.659^{* * *}$ & .000 \\
\cline { 2 - 6 } & 의문 & 일반 & 자폐 & -.483 & .482 \\
\multirow{2}{*}{$p<.01,{ }^{* * *} p<.0001}$.
\end{tabular}

\subsection{2. 강도(intensity) 차이 분석}

세 개의 강도 변수 중 IntMedian(강도 중앙값)은 문장 무선효 과가 유의하지 않았고, IntRange(강도 범위)와 IntDev(강도 표준 편차)는 문장 무선효과가 유의하였다. 분산분석 결과는 표 10 에 제시하였다. 강도 중앙값은 집단 간 통계적으로 유의하였으며, 강도 범위와 강도 표준편차는 집단과 문장 주효과와 문법 · 문 장 상호작용에서 유의한 차이를 보였다. Bonferroni 사후검정 실 시 결과, 모든 문법유형에서 자폐범주성 아동 집단이 모든 강도 
변수 값에서 유의하게 높았다. 문법 유형별 집단에 대한 강도 변수의 Bonferroni 사후검정 결과는 표 11에서 볼 수 있다.

표 10. 강도 변수에 대한 3 원 혼합모형 분산분석 검정 결과 Table 10. The result of three-way mixed effects ANOVA test on the intensity variables

\begin{tabular}{|c|c|c|c|c|}
\hline 변수 & 주효과 또는 상호작용 & 자유도 & $F$ & $p$-value \\
\hline \multirow{4}{*}{ IntMedian } & 집단 & 1 & $137.571^{* * *}$ & .000 \\
\hline & 문법 & 1 & 1.463 & .227 \\
\hline & 집단×문법 & 1 & .321 & .571 \\
\hline & 오차 & 981 & & \\
\hline \multirow{7}{*}{ IntRange } & 집단 & 1 & $29.029^{* * * *}$ & .000 \\
\hline & 문법 & 1 & .410 & .538 \\
\hline & 문장 & 9 & $18.015^{* *}$ & .001 \\
\hline & 집단×문법 & 1 & .104 & .754 \\
\hline & 문법×문장 & 9 & $3.360^{*}$ & .043 \\
\hline & 집단×문장 & 9 & .712 & .690 \\
\hline & 집단×문법×문장 & 9 & .461 & .901 \\
\hline \multirow{8}{*}{ IntDev } & 집단 & 1 & $16.090^{* *}$ & .003 \\
\hline & 문법 & 1 & 2.615 & .140 \\
\hline & 문장 & 9 & $10.861^{* *}$ & .003 \\
\hline & 집단×문법 & 1 & 1.020 & .339 \\
\hline & 문법×문장 & 9 & $4.405^{*}$ & .019 \\
\hline & 집단×문장 & 9 & .564 & .797 \\
\hline & 집단×문법×문장 & 9 & .671 & .784 \\
\hline & 오차 & 945 & & \\
\hline
\end{tabular}

표 11. 문법 유형별 집단에 대한 강도 변수의 Bonferroni 사후검정 결과 Table 11. The result of Bonferroni post-hoc test for the intensity variables on the groups by sentence types

\begin{tabular}{c|c|c|c|c|c}
\hline 변수 & 문법 & 집단(I) & 집단(J) & 평균차이(I-J) & $p$-value \\
\hline \multirow{2}{*}{ IntMedian } & 평서 & 일반 & 자폐 & $-4.454^{* * *}$ & .000 \\
\cline { 2 - 5 } & 의문 & 일반 & 자폐 & $-4.906^{* * *}$ & .000 \\
\hline \multirow{2}{*}{ IntRange } & 평서 & 일반 & 자폐 & $-3.259^{* * *}$ & .000 \\
\cline { 2 - 5 } & 의문 & 일반 & 자폐 & $-3.052^{* * *}$ & .000 \\
\hline \multirow{2}{*}{ IntDev } & 평서 & 일반 & 자폐 & $-.905^{* * *}$ & .000 \\
\cline { 2 - 5 } & 의문 & 일반 & 자폐 & $-.711^{* * *}$ & .000 \\
\hline
\end{tabular}

$$
{ }^{* * *} p<.0001 \text {. }
$$

\subsection{3. 발화 속도(speaking rate) 차이 분석}

말속도(speaking rate)와 조음속도(a-rate)가 집단, 문법, 문장 의 모든 주효과에서 유의한 차이를 보였고, 집단×문법 상호작 용 항에서 통계적으로 유의하였다. Bonferroni 사후 검정 결과. 자폐범주성 장애 아동 집단의 말속도와 조음 속도가 일반 아동 집단보다 모든 문법 유형에서 통계적으로 유의한 차이가 있었 다. 모든 값에서 자폐범주성 장애 아동 집단이 느린 말속도와 조음속도를 보였다. 3 원 혼합 모형 분산분석의 결과는 표 12 에, Bonferroni 사후검정 결과는 표 13 에 제시하였다. 강도 변수의 집단 간 차이를 확인할 수 있다.
표 12. 속도 변수에 대한 3 원 혼합모형 분산분석 검정 결과 Table 12. The result of three-way mixed effects ANOVA test for speaking anr articulation rate

\begin{tabular}{|c|c|c|c|c|}
\hline 변수 & 주효과 또는 상호작용 & 자유도 & $F$ & $p$-value \\
\hline \multirow{7}{*}{$\begin{array}{c}\text { Speaking } \\
\text { rate }\end{array}$} & 집단 & 1 & $55.743^{* * *}$ & .000 \\
\hline & 문법 & 1 & $60.671^{* * *}$ & .000 \\
\hline & 문장 & 9 & $7.029^{* *}$ & .002 \\
\hline & 집단×문법 & 1 & $31.783^{* * *}$ & .000 \\
\hline & 문법×문장 & 9 & $3.419^{*}$ & .041 \\
\hline & 집단×문장 & 9 & 2.525 & .092 \\
\hline & 집단×문법×문장 & 9 & .221 & .992 \\
\hline \multirow{8}{*}{ a_rate } & 집단 & 1 & $43.714^{* * *}$ & .000 \\
\hline & 문법 & 1 & $69.309^{* * * *}$ & .000 \\
\hline & 문장 & 9 & $8.725^{* *}$ & .001 \\
\hline & 집단×문법 & 1 & $28.777^{* * *}$ & .000 \\
\hline & 문법×문장 & 9 & 3.125 & .052 \\
\hline & 집단×문장 & 9 & 2.215 & .126 \\
\hline & 집단×문법×문장 & 9 & .244 & .988 \\
\hline & 오차 & 945 & & \\
\hline
\end{tabular}

표 13. 문법 유형 별 집단에 대한 속도 변수의 Bonferroni 사후검정 결과 Table 13. The result of Bonferroni post-hoc test for speaking rate variables

\begin{tabular}{c|c|c|c|c|c}
\hline 변수 & 문법 & 집단(I) & 집단 $(\mathrm{J})$ & 평균차이(I-J) & $p$-value \\
\hline \multirow{2}{*}{ Spaking rate } & 평서 & 일반 & 자폐 & $.218^{* * *}$ & .007 \\
\cline { 2 - 6 } & 의문 & 일반 & 자폐 & $.520^{* * *}$ & .000 \\
\hline \multirow{2}{*}{ a_rate } & 평서 & 일반 & 자폐 & $.174^{*}$ & .028 \\
\cline { 2 - 6 } & 의문 & 일반 & 자폐 & $.468^{* * *}$ & .000 \\
\hline \multirow{2}{*}{$p<.05,{ }^{* * *} p<.01,{ }^{* * * *} p<.0001}$.
\end{tabular}

\subsection{4. 문미 마지막 2음절 음도 기울기(slope) 차이 분석}

3 개 음도기울기 변수는 집단과 문법 주효과에서 모두 유의 하였고, 집단·문법 상호작용 항에서도 모두 유의한 차이를 보였다. Bonferroni 사후검정 결과, 평서문에서 s2_Slope(문미 억양구 회귀 기울기)와 diff_s2_Slope(문미 말 2개 음절 변화량 기울기)에는 유의한 차이를 보였다. 의문문에서 s2_meanAbsSlope (문미 억양구 억양 굴곡 변이량)을 포함한 모든 변수에서 일반 아동 그룹이 높은 값을 보이며 통계적으로 유의하였다. 음도기 울기 변수의 차이는 표 14 의 Bonferroni 사후검정 결과에 제시 하였다.

표 14. 문법 유형별 집단에 대한 음도 기울기 변수의 Bonferroni 사후검정 결과

Table 14. The result of Bonferroni post-hoc test for pitch slope variables on the groups by sentence types

\begin{tabular}{c|c|c|c|c|c}
\hline 변수 & 문법 & 집단(I) & 집단 $(\mathrm{J})$ & 평균차이(I-J) & $p$-value \\
\hline \multirow{2}{*}{ s2_Slope } & 평서 & 일반 & 자폐 & .035 & .789 \\
\cline { 2 - 6 } & 의문 & 일반 & 자폐 & $1.525^{* * *}$ & .000 \\
\hline \multirow{2}{*}{ s2_meanAbsSlope } & 평서 & 일반 & 자폐 & $-73.949^{* * *}$ & .000 \\
\cline { 2 - 6 } & 의문 & 일반 & 자폐 & $171.551^{* * *}$ & .000 \\
\hline \multirow{2}{*}{ Diff_s2_Slope } & 평서 & 일반 & 자폐 & .026 & .911 \\
\cline { 2 - 6 } & 의문 & 일반 & 자폐 & $2.471^{* * *}$ & .000 \\
\hline \multirow{2}{***}{$p<.0001}$.
\end{tabular}


그림 2는 문미 마지막 두 음절에서 일반아동 집단과 자폐범 주성 장애아동 집단 간 평서문과 의문문의 s2_Slope 그래프다. 아래의 검은 선은 평서문의 기울기 평균값이고 위 붉은 선은 의 문문의 기울기 평균값이다. 평서문에 비해 의문문의 기울기 값 의 편차가 크게 나타난 것을 확인할 수 있다. 또한, 그림 3을 통 해 문미 마지막 두 음절의 집단 간 기울기 차이를 확인할 수 있 다(그림 2, 그림 3).

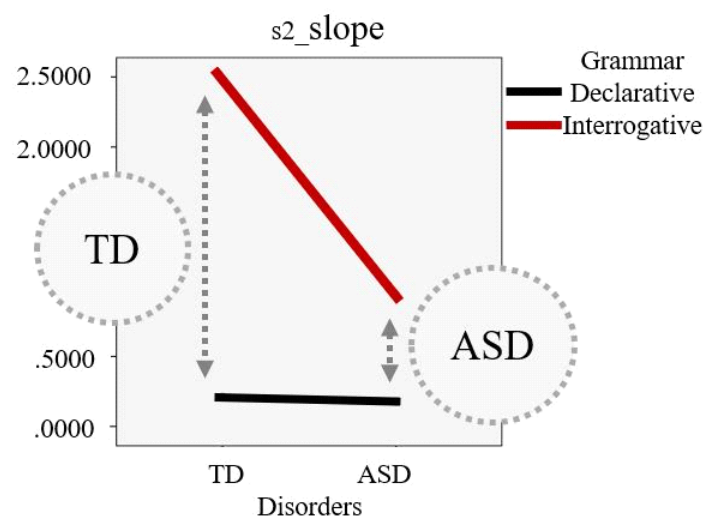

그림 2. 문미 마지막 두 음절의 일반 아동 집단과 자폐범주성 장애 아동 집단 간 $\mathrm{S} 2$ Slope 차이

Figure 2. S2_Slope of last two syllables in sentences by TD(typically developing) and $\mathrm{ASD}$ (autism spectrum disorders) groups
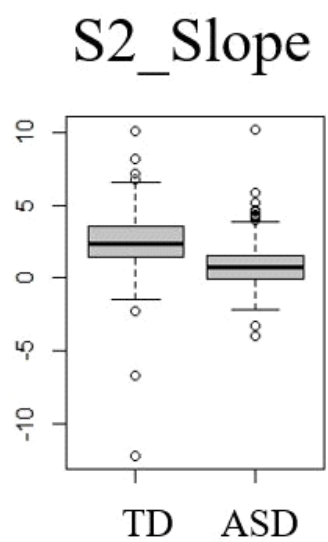

그림 3. 문미 마지막 두 음절의 집단 간 s2_Slope 차이

Figure 3. s2_Slope difference of the last two syllables in sentences by groups

3.2. 문미 음절수 증가에 따른 의문문 어말 음도기울기 분석 어말 음절길이를 1 음절부터 5 음절까지 늘려가는 문장 데이 터를 사용하여 집단과 문법 유형을 고정 변수로, 길이 증가 변 수를 임의 무선변수로 설정한 후 마지막 어절의 두 음절 기울기 가 집단간, 문법유형간 차이가 있는지 살펴보았다(마지막 어절 이 1 음절로 이루어진 경우는 그 1 음절의 기울기를 측정 대상으 로 하였다; 표 2 참고). 3원 혼합 모형 분산분석에서 s2_Slope 변 수의 길이 무선 효과는 유의하지 않았다. Bonferroni 사후 검정 결과, 일반 아동 집단은 1 음절-5음절 모두 문법 유형 간 음도기 울기가 유의한 차이를 보였다. 반면 자폐범주성 장애 아동 집단
은 문법 유형 간 1 음절, 3 음절과 4음절에서 유의한 차이를 보였 다. 1 음절에서 가장 큰 차이를 보였고 5 음절에서 가장 작은 차 이를 보였다. 검정 결과는 표 15 에 제시하였다.

표 15. 음절 수 증가에 따른 기울기 변수의 Bonferroni 사후검정 결과 Table 15. The result of Bonferroni post-hoc test for pitch slope variables according to the increasing number of sentence final syllable

\begin{tabular}{c|c|c|c|c}
\hline 변수 & 집단 & 음절수 & $\begin{array}{c}\text { 문장유형 간 평균차이 } \\
\text { (평서-의문) }\end{array}$ & $p$-value \\
\hline \multirow{4}{*}{ s2_Slope } & \multirow{3}{*}{ 자폐 } & 1음절 & $-1.597^{* *}$ & .001 \\
\cline { 3 - 5 } & 2음절 & -.520 & .129 \\
\cline { 3 - 5 } & 3음절 & $-.881^{*}$ & .010 \\
\cline { 3 - 5 } & 4음절 & $-1.119^{*}$ & .023 \\
\cline { 3 - 5 } & 5음절 & -.199 & .563 \\
\hline${ }^{*} p<.05,{ }^{* *} p<.01$. & \multicolumn{4}{|l}{}
\end{tabular}

3.3. 일반 아동 집단과 자폐범주성 장애 아동 집단 간 문법 유형에 따른 청자의 지각적 특성

일반 아동 집단과 자폐범주성 장애 아동 집단이 산출한 평서 문과 의문문을 청자가 얼마나 정반응 지각하는지 카이제곱 검 정을 하였다. 평서문의 경우 자폐범주성 장애 아동 집단이 산출 한 평서문에서 청자지각의 정반응(평서문을 평서문으로 지각) 은 140 개 중 134개(95.7\%)로 일반 아동 집단(210/210, 100\%)과 큰 차이가 나지 않았다. 그러나 의문문의 경우 일반 집단과 자 폐범주성 장애 집단 데이터에 대한 의문문 정반응 빈도 사이에 큰 차이가 관찰되었다. 일반 집단 데이터의 경우 총 210 반응 중 207개(98.6\%)가 의문 반응으로 정반응하였고, 자폐범주성 장애 집단 데이터는 140 개 자극 중에서 6 개(4.3\%)만 정반응하였다. 의 문문 자극에 대한 청자의 지각 반응 차이는 표 16 에 제시하였다.

표 16. 의문문 자극에 대한 집단 간 청지각 정반응 차이*

Table 16. The differences of perceptional positive responses on the interrogative sentences between two groups

\begin{tabular}{c|c|c|c|c|c|c}
\hline \multirow{2}{*}{ 집단 } & \multicolumn{2}{|c|}{ Positie response } & \multirow{2}{*}{ 전체 $\mathrm{N}(\%)$} & \multirow{2}{*}{ 카이제곱 $\left(\chi^{2}\right)$} & 자유도 & $p$-value \\
\cline { 2 - 4 } & 평서 & 의문 & & & \\
일반 & 3 & 207 & 210 & & & \\
& $(1.4 \%)$ & $(98.6 \%)$ & $(100 \%)$ & \multirow{2}{*}{313.478} & 1 & .000 \\
\hline \multirow{2}{*}{ 자폐 } & $\begin{array}{c}134 \\
(95.7 \%)\end{array}$ & $\begin{array}{c}6 \\
(4.3 \%)\end{array}$ & $\begin{array}{c}140 \\
(100 \%)\end{array}$ & & & \\
\hline
\end{tabular}

* 정반응이란 평서문 발화를 평서문으로 지각, 혹은 의문문 산출 을 의문문으로 지각한 경우를 말한다(The positive response is a case in which the utterance of a declarative sentence is perceived as a declarative sentence or vice versa).

\section{4. 결론 및 논의}

자폐범주성 장애 아동 집단과 일반 아동 집단을 대상으로 평 서문과 의문문 따라말하기를 통해 음향음성학적 특징을 살피 고 청지각 평가를 실시하여 자폐범주성 장애 아동 집단의 의문 문 반응 분포를 살펴보았다. 음향음성학적 분석에서는 각 문법 유형(평서, 의문문)의 문장 전체와 문미 어절의 음도와 강도, 발 화 속도, 음도기울기 차이를 집단 간 비교하였다. 또한 의문문 
산출 시 문미 음절증가 효과와 청지각 평가를 통한 지각적 특성 을 제시하였다.

음도 변수 분석 결과, 평서문에서는 자폐범주성 장애 아동 집 단이 음도 중앙값, 음도 표준편차와 쿼터톤 값이 유의하게 높았 으며 음도 범위가 더 넓었다. Sharda et al.(2010)의 평서문 자발 화 산출 과제에서 상대적으로 높은 음도와 넓은 음도 범위를 보 인다는 연구와 일치한다. 의문문에서는 자폐범주성 장애 집단 의 음도 중앙값이 높았지만 음도 표준편차가 작고 음도 범위가 일반 아동 집단에 비해 좁았다. 이는 자폐범주성 장애 아동이 일반 아동에 비해 음도기울기가 낮아 억양의 변화가 거의 없음 을 의미하는 결과다. 음도 범위는 평서문에서는 자폐범주성 장 애 아동이 일반 아동보다 넓었지만, 의문문에서는 더 좁았다. 일반 아동은 의문문에서 마지막 낱말을 높여 의문문에서 음도 범위가 커지지만 자폐범주성 장애 아동은 음도의 변화가 없어 음도 범위가 좁게 나타난 것으로 볼 수 있다. 이는 Baltaxe \& Simmons(1985)의 선행연구에서 자폐범주성 장애 아동의 음도 범위가 의문문에서 더 좁다는 결과와 일치한다.

평서문과 의문문에서 집단 간 강도 차이를 살펴보았을 때 모 든 강도 변수가 유의하여 문장 강도 중앙값, 강도 표준 편차가 일반 아동 집단에 비해 자폐범주성 장애 아동 집단이 더 높았으 며 강도 범위 또한 일반 아동 집단보다 넓었다. 자폐범주성 장 애 아동의 상대적으로 높은 강도는 $\operatorname{Lim}(2009)$ 의 읽기 과제를 통 한 연구에서 고기능 자폐 아동이 일반 아동보다 높은 강도를 사 용한다는 결과와 일치한다. 같은 읽기 과제를 통한 두 연구의 결과에 차이가 있었지만 이는 읽기 과제 문장의 차이 때문에 다 른 결과가 도출될 수 있다고 하였다. 이러한 연구와 같이 강도 범위와 강도 표준 편차는 문장 간 유의한 차이가 있었다. '내일 만나, 머리 말려, 여기 놨어요.' 문장에서 자폐범주성 장애 아동 이 일반 아동보다 높은 강도 값을 보였는데 이는 ‘나비가 날아 요, 엄마가 노래해’등의 설명문보다 일상생활에서 많이 쓰는 어 휘로 구성되어 있는 문장이기 때문에 큰 강도 값을 보였다고 추 측된다.

연구에서 의문문의 경우 자폐범주성 장애 아동 집단의 음도 편차보다 강도편차가 더 주목을 받는 결과를 보여주었다. 일반 아동은 자폐범주성 아동에 비해 의문문에서 음도편차는 더 큰 반면 강도편차는 상대적으로 작은 것으로 조사된 것인데 발화 의 힘이 집중되는 어두에서 자폐범주성 아동 집단 발화가 강도 의 관점에서 편차를 많이 주면서 발화된 것으로 짐작된다.

말속도와 조음 속도는 모두 일반 아동 집단이 자폐범주성 장 애 아동 집단보다 모든 문법 유형(평서, 의문)에서 유의하게 빨 랐다. 자폐범주성 장애 집단 아동의 상대적으로 느린 발화 속도 는 읽기 과제를 통한 Pronovost(1966)의 발화 속도 연구와 일치 한다.

문미 마지막 두 음절의 음도기울기 차이를 보면 평서문 산출 시 일반 아동과 자폐범주성 장애 아동간의 문미 억양구 회귀 음 도기울기와 음도 변화량 기울기 값에 유의한 차이가 없었다. 의 문문에서는 모든 변수에서 유의미하며 일반 아동이 자폐범주 성 장애 아동에 비해 높은 음도기울기 값을 보였다. 이는 자폐
범주성 장애 아동이 일반 아동보다 단조로운 운율로 의문문을 산출 한다는 것을 의미한다. 읽기 과제에서 평서문 산출 시 일 반 아동과 자폐범주성 장애 아동의 억양패턴은 유사하며, 의문 문 산출 시 두 집단 모두 마지막 음절에서 음도기울기 값이 커 진다는 $\operatorname{Kim}(2004)$ 의 연구와 일치한다.

자폐범주성 장애 아동은 문법 유형에 관계없이 상대적으로 높은 음도, 더 센 강도로 발화한다. 하지만 의문문에서 더 빠르 게 발화하며 마지막 두 음절에서 올림조를 사용한다. 자폐범주 성 장애 집단의 음도와 강도 변수가 평서문과 의문문에서 유의 한 차이를 보이지 않는 것이 자폐범주성 장애 아동 집단이 일반 아동 집단과 운율 차이를 보이는 주요 요인으로 생각할 수 있다. 그러나 Fosnot \& Jun(1999)은 책읽기와 모방 과제를 통한 운율 실험에서 자폐 범주성 아동이 단어 강세와 문장 강세에서 모두 잘못된 배치를 나타내었다고 보고하였다. 문장 따라말하기는 아동의 모방이 문법지식을 보여준다는 가정을 전제로 하여 (Lee, 2001), 자신의 단기 기억력을 초과한 문장도 따라 말할 수 있는 것은 자신이 가진 언어지식을 활용하기 때문이라고 하였 다(Hale-Haniff \& Siegel, 1981). 아동은 성인의 문장을 발달에 적 합한 그들의 심층구조 문법지식에 맞춰 말하는 것이며, 아직 발 달되지 못한 체계들이 따라말하기 과제 중 생략, 대치되어 표면 구조에 나타나게 된다(Lee, 2001). 이러한 이유로 상승조의 의문 문 억양 산출은 자폐성 정도 및 따라말하기와 관련된 능력에 따 라 인지기능이 우수한 아동일수록 적절한 억양을 산출한다고 했다. 자폐범주성 장애 아동의 사회성 및 의사소통 능력의 결핍 은 말의 운율 특성과도 관계한다. Hargrove(1997)는 의사소통 능 력의 결핍으로 자폐범주성 장애 아동의 부적절한 강세의 사용 이나 일반적이지 않은 억양패턴이 나타났다고 하였다.

문미 어절을 1 음절에서 5 음절까지 증가시켜가며 그 어절의 음도기울기 값을 분석한 결과, 일반 아동의 경우 1 음절에서 5 음 절까지 모든 음도기울기 변수에서 의문문이 평서문보다 유의 하게 높았으나, 자폐범주성 장애 아동은 1 음절에서만 모든 음 도기울기 변수가 유의하게 차이를 보였으며 의문문의 음도기 울기 값이 더 높았다. 또한, 3음절과 4음절에서는 문미 억양구 회귀 기울기와 문미 말 2개 음절 변화량 기울기에 유의한 차이 를 보였다. 평균 차이를 봤을 때, 문미가 5음절로 이루어진 문장 산출시 음도기울기 값이 가장 유의하지 않았다. 자폐범주성 장 애 아동이 의문문 산출 시 5음절로 이루어진 문장보다 문미 길 이가 가장 짧은 1 음절로 이루어진 문장에서 큰 음도기울기를 보인다. 결과적으로 일반 아동은 문미 음절 수 증가에 영향을 받지 않지만 자폐 범주성 장애 아동은 짧은 의문문 문장 발화 시 상승조를 보여 긴 문장보다 짧은 문장에서 의문문 억양을 보 인다는 것을 의미한다. 자폐 아동이 짧은 문장에서 음도기울기 값이 커진다는 연구 결과(Cooper \& Sorensen, 1981)와 이 연구의 1음절과 5음절을 비교하였을 때 일치하는 결과다. 그러나 일반 아동의 음도기울기 값에서 짧은 음절일수록 의문문에서 높은 음도기울기를 보인다는 관찰은 우리말에서 F0의 기울기는 문 장길이에 영향을 받지 않는다는 $\mathrm{Ko}(1988)$ 의 연구결과와 일치하 지 않는다. 
자폐범주성 장애 아동의 평서문 및 의문문 산출과 청자의 지 각과의 관계를 살펴보면, 자폐범주성 장애 아동이 산출한 평서 문에서 청자는 $95.7 \%$ 의 정반응을 보여 통계적으로 유의하였다. 자폐범주성 장애 아동이 산출한 의문문에 대한 청지각 정반응 률은 $4.3 \%$ 로, 청자는 자폐범주성 장애 아동의 의문문을 평서문 으로 지각한다는 것을 알 수 있다. 자폐범주성 장애 아동의 평 서문과 의문문은 음도와 강도에는 유의한 차이가 없었고, 속도 와 음도기울기에만 유의한 차이가 있었다. Nadig \& Shaw(2012) 의 연구에서 자발화 과제 상황에서 자폐 아동이 음도 범위에서 높은 값을 가졌고, 청지각적 평가에서 1-7점 척도를 이용하여 점수를 산출한 결과, 고기능 자폐스펙트럼 아동이 전체적인 인 상에서 유의하게 낮은 점수를 나타냈다. 이러한 선행연구를 통 해 청자는 자폐 아동의 의문문을 지각하여 구분할 수 있는 음향 학적 특성이 속도와 음도기울기가 아닌 음도나 강도의 차이로 인해 의문문을 지각할 수 있다고 추측할 수 있다.

이상의 결과를 종합하여 다음과 같이 정리할 수 있다. 평서문 과 의문문 따라말하기에서 자폐범주성 장애 아동이 일반 아동 에 비해 음도와 강도가 높고, 발화 속도가 느리며, 음도 기울기 가 낮았다. 또한, 자폐범주성 장애 아동은 의문문과 평서문에서 음도와 강도의 유의한 차이를 보이지 않았다. 이러한 운율 특성 때문에 청자가 의문문을 평서문으로 지각하는 문제를 보임으 로써 자폐범주성 장애 아동이 운율 능력에 결함이 있음을 확인 할 수 있었다. 비일반적인 억양 패턴은 지각적인 부분이나 운동 신경에서의 결함이 원인일 수 있다. 또한 화용 능력의 결함이나 다른 자폐적 특징의 결함과 관련되어 있다고도 한다(Paul, 1987). 그러나 자폐범주성 장애 아동의 비일반적인 운율 문제의 원인은 정확하게 규명되지 않았으며 청지각 평가를 통해 청자 는 음도와 강도의 유의한 차이를 구분하기 어려워 대부분 자폐 범주성 장애 아동의 의문문을 평서문으로 지각한다는 결과를 확인할 수 있었다. 결론적으로 자폐범주성 장애 아동의 운율에 결함이 있음을 인지하고 음도와 강도의 모방을 통한 치료 중재 연구가 필요하다고 판단된다. 이 연구는 자폐범주성 장애 아동 의 운율 능력 향상을 위해서 자폐범주성 장애 아동의 음도, 강 도, 속도, 음도기울기 산출 능력을 음향학적으로 평가하고 임상 적 측면에서 운율 개선을 통한 의문문 산출로 인한 의사소통 표 현 증진을 위한 효과적 중재적 접근에 필요한 기초자료를 구축 하는데 있다. 또한 치료 개발의 필요성과 문미의 길이를 조절한 치료 중재의 필요성을 제시했다는데 의의가 있다고 볼 수 있다. 이 연구는 자폐범주성 장애 아동의 임상에서 치료 중재에 많이 쓰이는 따라말하기를 통한 억양 모방의 가능성을 본 연구였지 만 자연스러운 환경에서의 자발화를 통한 억양 분석에서도 같 은 결론을 보이는지 살펴볼 필요가 있다. 자폐 범주성 장애 아 동의 인지능력을 고려하여 인지능력에 따른 억양의 차이를 보 는 연구가 필요하다. 또한 청유문이나 명령문 등의 다양한 문법 유형에서 운율능력을 살펴보는 연구와 자폐범주성 장애 아동 과 일반아동뿐만 아니라 다른 장애를 가진 아동들 간의 운율 비 교연구가 이루어질 필요가 있다.

\section{References}

Baltaxe, C. A. M., \& Simmons III, J. Q. (1985). Prosodic development in normal and autistic children. In E. Schopler, \& G. B. Mesibov (Eds.), Communication problems in autism. Boston, MA: Springer (pp. 95-25).

Cutler, A., \& Isard, S. (1980). The production of prosody. In B. Butterworth (Ed.), Language production 1 (pp. 245-269). London, UK: Academic Press.

Cooper. W. E., \& Sorensen, J. M. (1981). Fundamental frequency in sentence production. New York, NY: Springer-Verlag.

Fletcher, E. C. (1976). A comparison of pitch patterns of normal and autistic children (Doctoral dissertation). University of California, Santa Barbara, CA.

Fox, W., \& Hampton, A. (2008). Stuttering and natural speech processing of semantic and syntactic constraints on verbs. Journal of Speech, Language, and Hearing Research, 51(5), 1058-1071.

Fosnot, S. M., \& Jun, S. A. (1999, August). Prosodic characteristics in children with stuttering or autism during reading and imitation. Proceedings of the 14th International Congress of Phonetic Sciences (pp. 1925-1928). San Francisco, CA.

Goldfarb, W., Goldfarb, N., Braunstein, P., \& Scholl, H. (1972). Speech and language faults of schizophrenia children. Journal of Autism and Childhood Schizophrenia, 2, 219-233.

Hargrove, P. (1997). Prosodic aspects of language impairment in children. Topics in Language Disorders, 17(4), 76-83.

Hale-Haniff, M., \& Siegel, G., M. (1981). The effect of context on verbal elicited imitation. Journal of Speech and Hearing Disorders, 46(1), 27-30.

Kim, H. W. (2004). Prosodic features in high functioning autism children (Master's thesis). Hallym University, Chuncheon, Korea.

Ko, D. H. (1988). Declarative intonation in Korean: An acoustical study of FO declination (Doctoral dissertation). University of Kansas, Lawrence, KS.

Lee, I. S. (1992). Research on Korean orthography. Seoul, Korea: SNU Press.

Lee, J. M. (2001). The production of grammatical morphemes of children with SLI in sentence repetition (Master's thesis). Dankook University, Cheonan, Korea.

Lee, Y. G. (1988). A study of Korean interrogative prosody, Hangeul, 191, 15-38.

Lim, S. M. (2009). Prosodic control of high functioning autism and normal children in relation to question-statement contrast. (Master's thesis). Ehwa University, Seoul, Korea.

Nadig, A., \& Shaw, H. (2012). Acoustic and perceptual measurement of expressive prosody in high-functioning autism: Increased pitch range and what it means to listeners. Journal of Autism and Developmental Disorders, 42(4), 499-511. 
Paul, R. (1987). Communication. In D. J. Cohen, \& F. R. Volkmar (Ed.), Handbook of autism and pervasive developmental disorders, New York, NY: John Wiley \& Sons.

Park, E. J. (2003). 4 to 8 year-old children's performance of repeating sentences according to the length and structure of sentences. (Master's thesis). Dankook University, Cheonan, Korea.

Pronovost, W., Wakstein, M. P., \& Wakstein, D. J. (1966). A longitudinal study of the speech behavior and language comprehension of fourteen children diagnosed atypical or autistic. Exceptional Children, 33(1), 19-26.

Tager-Flusberg, H., \& Thurber, C. (1993). Pauses in the narratives produced by autistic, mentally retarded, and normal children as an index of cognitive demand. Journal of Autism and Developmental Disorders, 23, 309-322.

Schwartz, A. H., \& Daly, D. A. (1976). Some explicit guidelines for constructing and scoring elicited imitation tasks. Language, Speech, and Hearing Services in Schools. 7, 33-41.

Seong, C. J. (1995). Experimental phonetic study of the standard current Korean speech rhythm: With respect to its temporal structure (Doctoral dissertation). Seoul National University, Seoul, Korea.

Sharkey, S. G., \& Folkins, J. W. (1985). Variability of lip and jaw movements in children and adults: Implications for the development of speech motor control. Journal of Speech, Language, and Hearing Research, 28(1), 8-15.

Sharda, M., Subhadra, T. P., Sahay, S., Nagaraja, C., Singh, L., Mishra, R., Sen, A., ‥ Singh, N. C. (2010). Sounds of melody-pitch patterns of speech in autism. Neuroscience Letters, $478(1), 42-45$.

\section{- 이진형 (Jinhyung Lee)}

충남대학교 언어병리학과 박사과정

대전 유성구 대학로 99

Tel: 042-821-6391

Email: jhlee240211@hanmail.net

관심분야: 언어발달장애, 운율분석

- 성철재 (Cheoljea Seong) 교신저자

충남대학교 언어학과 교수

대전 유성구 대학로 99

Tel: 042-821-6395

Email: cjseong49@gmail.com

관심분야: 분절음 및 운율분석 


\title{
따라말하기 과제를 통한 자폐범주성 장애 아동과 일반 아동의 평서문과 의문문의 음향학적 특성 비교*
}

\author{
이 진 형'성 철 재 ${ }^{2}$
}

1충남대학교 언어병리학과, ${ }^{2}$ 충남대학교 언어학과

\begin{abstract}
국문초록
언어의 운율은 억양, 리듬, 강세로 구성되어 있고 운율 요소는 상호 복합적인 작용을 통하여 언어의 고유한 리듬을 형성한다. 자폐범주성 장애 아동은 자연스러운 운율 학습에 어려움이 있어 정확한 의미와 정보 전달에 어려움이 있어 자폐범주성 장애 아동의 운율에 대한 연구가 중요하다. 평서문과 의문문 따라말하기 과제를 통하여 자폐범주 성 장애 아동 집단과 일반 아동 집단 간의 운율 특성 차이를 구명하고 어말 길이에 따라 의문문에서의 음도기울기 와 청자와의 지각관계를 알아보았다. 7-12세 일반 아동 30명, 자폐범주성 장애 아동 20 명을 대상으로 언어 평가 후 20 문장 따라말하기 과제를 실시하였다. 청지각 과제로는 115 문장이 사용되었다. 자폐범주성 장애 아동이 일반 아 동에 비해 음도와 강도가 높고, 발화속도가 느리며 음도 기울기가 낮았다. 자폐범주성 장애 아동은 평서문과 의문 문의 산출에서 음도와 강도에 유의한 차이를 보이지 않았다. 자폐범주성 장애 아동은 의문문 1 음절에서 평서문과 가장 큰 기울기 차이를 보였으며 5 음절 의문문 산출에서 가장 낮은 기울기 값을 보였다. 청지각 평가 결과 청자는 $4.3 \%$ 만 자폐범주성 장애 아동의 의문문을 의문문으로 지각하였다. 결과적으로 평서문과 의문문 따라말하기에서 자폐범주성 장애아동이 일반 아동에 비해 음도와 강도가 높고, 발화속도가 느리며, 낮은 음도기울기를 보였다. 이 러한 운율패턴 때문에 청자는 의문문을 평서문으로 인식하였고 원인은 규명되지 않았지만 화용능력이나 다른 자 폐적 특징의 결함과 관련이 있다고 할 수 있다. 본 연구에서는 자폐범주성 장애 아동의 이러한 억양 패턴을 확인하 였고 운율 개선을 위한 치료 개발의 필요성을 제시했다.
\end{abstract}

핵심어: 자폐, 운율, 평서문, 의문문

\section{참고문헌}

김해원 (2004). 고기능 자폐아동의 억양특성. 한림대학교 석사학 위논문.

박은주 (2003). 문장의 길이와 구조에 따른 4-8세 아동의 문장따 라말하기 수행력. 단국대학교 특수교육대학원 석사학위논문.

이정미(2001). 문장따라말하기에서 나타난 단순언어장애 아동 의 조사처리능력. 단국대학교 석사학위논문.

성철재 (1995). 한국어 리듬의 실험음성학적 연구. 시간구조와 관 련하여, 서울대학교 박사학위논문.

이영길 (1988). 한국어 의문문의 억양 의미, 한글, $191,15-38$. 이익섭 (1992). 국어 표기법 연구. 서울: 서울대학교출판부.

임세미 (2009). 의문문과 평서문 읽기 과제를 통한 고기능 자폐아동 과 일반아동의 운율통제 비교 이화여자대학교 석사학위논문.

\footnotetext{
* 이 논문은 2019년 한국음성학회 봄 학술대회 발표논문을 수정, 보완한 것입니다.
} 